DOI:

UDK 004.942:519.62: 519.683

L.I. Korotka, Candidate of Technical Sciences (Ph. D.), Docent, korliv@hotmail.com

O.S. Rott, survare@hotmail.com

Ukrainian State University of Chemical Technology, Dnipro

\title{
INFORMATION SUPPORT OF MODELING FOR NONLINEAR DYNAMIC SYSTEMS BY COMPETITION OF SPECIES
}

In the work the software toolkit for simulation modeling of nonlinear dynamical systems is developed and described. A class of tasks related to the competition of species is considered and has an applied value in natural, social, economic sciences, and others like that. Information support allows for qualitative research and analysis of systems on the models Lotka-Volterra, Jacob-Monod, HollingTanner. For their realization, one-and multi-step numerical methods are used. The software toolkit is equipped with visualization elements, in particular $2 D$ and $3 D$ graphics.

Keywords: nonlinear dynamical system;, qualitative research; Lotka-Volterra; Jacob-Monod; Holling-Tanner.

У роботі розроблено та описано програмний інструментарій для імітаиійного моделювання нелінійних динамічних систем. Розглянуто клас задач, які відносяться до конкурениї видів та мають прикладне значення у природничих, суспільних, економічних науках, тощо. Інформачійне забезпечення дозволяє проводити якісне дослідження та аналіз систем на моделях Лотки-Вольтерри, Жакоба-Моно, Холлінга-Теннера. Для їх реалізаиії застосовано одно та багатокрокові чисельні методи. Програмний інструментарій оснащено елементами візуалізаиії, зокрема, $2 D$ та $3 D$ графікою.

Ключові слова: нелінійні динамічні системи; якісне дослідження; Лотка-Вольтерра; Жакоба-Моно; Холлінга-Теннера.

\section{Formulation of the problem}

For modeling complex dynamic systems (DS) and processes is used to special software. There are a large number of software tools available for this type of task, such as GPSS, AnyLogic, Matlab, and many others. As you know, each of them has its own advantages and disadvantages, in particular, in the majority they solve a very wide range of tasks, have a powerful visual interface, but are quite expensive software, and in the case of free access (for example, the environment GPSS) solve a limited class of tasks. For the educational process, the need to study and research dynamic systems is quite relevant, so the development and creation of software tools to work with them is undeniable.

\section{Analysis of recent research and publications}

As a rule, mathematical models in the form of differential equations and their systems, integral-differential equations, etc. are used for analytical description of dynamic systems [1-3], so numerical methods are generally used to solve them, for example: Runge-Kutta methods of different orders and their modifications, the Adams-Bashfort method and others. There are quite a number of papers devoted to numerical methods, for example [4], so the authors do not dwell on them separately.

It is known that the main components of nonlinear dynamic systems are: stability theory, dynamic chaos theory, ergodic theory, and integrated systems theory $[5,6]$. Obviously, these components represent an entire scientific layer that cannot be grasped in one work, so the authors narrow the field of nonlinear dynamic systems and consider systems of competition of species. Note that nonlinear dynamic systems (species competition, in particular) are of sufficiently large applied value and are used in biology and medicine, economics and ecology, sociology and social sciences, etc. [5-8]. Mathematical models of such systems allow to quantify the status, functioning and dynamics of populations, their interaction.

\section{Formulation of the study purpose}

Dynamic systems research is known to be possible using appropriate software products, some of which are described above. The purpose of the work is to create software that allows to obtain numerical solutions of DS using separate classes of numerical methods and has a visual interface. The 
software contains a plugin system, each of which is a dynamic model that has its own data (model name, model formulas, its description, coefficients names, model roles, initial values of roles and parameters) and a numerical resolution algorithm. The main task of the work is the design and development of software tools for simulation modeling in order to study nonlinear dynamic systems of competition of species.

\section{Presenting main material}

As you know, an integral element of modeling is a description of the structure and function of the system under development. Here is a list of structural elements that make up the system, the relationship between them and their functions:

1) working with external data. Ability to export the results of the program as a report for easy viewing and saving of settings in a file for further loading into the system;

2) work with plugins and dynamic models. Downloading plugins, that is, downloading .dll (for Windows) files from a special plugins directory into the system for further processing. Carrying out calculations with certain parameters passed to the plug-in instance, returning the calculation results for further processing in the system;

3) visualization of results. The results of the work after the calculations should be displayed in certain types (2D time-population diagram, 3D graph, results table, phase portrait of the system). It is possible to review the performance results for all or some of the numerical integration methods to perform calculations and research;

4) display controls. In order to work with the program, you must arrange the controls so that it is clear how to work with it. Main elements: Integration Control Panel (Beginning, End and Step Integration, Selection of the Dynamic Model), Panel of Initial Population Determination, Odds Panel (After Model Loading, It Fills Initial Values), 2D and 3D graphics, phase portrait, results table.

Mathematical support. Without limitation of judgments, the following nonlinear dynamic models are considered in the work: Lotka-Volterra; Holling-Tanner; Lotka-Volterra with logistic amendment; Jacob-Monod and Voltaire's "predator-victim-victim" (table 1).

Table 1. Mathematical models used in the work

\begin{tabular}{|c|c|}
\hline Mathematical model of a dynamic system & Model options \\
\hline $\begin{array}{l}\text { Lotka-Volterra model: } \\
\qquad \begin{array}{l}\frac{d x}{d t}=x(\alpha-\beta y) \\
\frac{d x}{d t}=-y(\gamma-\delta x)\end{array}\end{array}$ & $\begin{array}{c}x-\text { the number of victims; } \\
y-\text { the number of predators; } \\
\alpha-\text { the birth rate of the victims; } \\
\beta-\text { the victim's meeting probability with the preda- } \\
\text { tor; } \\
\gamma-\text { the birth rate of predators; } \\
\delta-\text { the ratio of reduction in the number of preda- } \\
\text { tors. }\end{array}$ \\
\hline $\begin{array}{l}\text { Lotka-Volterra model with logistic } \\
\qquad \begin{array}{l}\frac{d x}{d t}=(a-b y) y-\alpha x^{2} \\
\frac{d y}{d t}=(-c+d x) y-\alpha y^{2}\end{array}\end{array}$ & $\begin{array}{c}a-\text { the birth rate of the victims; } \\
b-\text { the meeting of victim's rate with the predator; } \\
c-\text { the birth rate of predators; } \\
d-\text { the ratio of reduction in the number of preda- } \\
\text { tors; } \\
\quad \alpha \text { - the attenuation factor. }\end{array}$ \\
\hline $\begin{array}{l}\text { Holling-Tanner model: } \\
\left\{\begin{array}{l}\frac{d x}{d t}=r\left(1-\frac{x}{K}\right) x-w y \frac{x}{D+x} \\
\frac{d y}{d t}=s\left(1-\frac{J y}{x}\right) y\end{array}\right.\end{array}$ & $\begin{array}{c}x-\text { the number of victims; } \\
y \text { - the number of predators; } \\
r, s, K, D, J \text { - positive constants. }\end{array}$ \\
\hline
\end{tabular}


Continue of the table 1.

\begin{tabular}{|c|c|}
\hline $\begin{array}{l}\text { Jacob-Monod model: } \\
\left\{\begin{array}{l}\frac{d x}{d t}=\frac{V y}{K+y} x \\
\frac{d y}{d t}=-\frac{1}{Y} \frac{V y}{K+y} x\end{array}\right.\end{array}$ & $\begin{array}{c}V-\text { the absorption rate; } \\
K-\text { the saturation factor; } \\
Y-\text { the number of bacteria per unit } \\
\text { nutrients. }\end{array}$ \\
\hline $\begin{array}{l}\text { Model Volterra "predator-victim-victim": } \\
\qquad \begin{array}{l}\frac{d x_{1}}{d t}=a_{1} x_{1}-b_{1} x_{1} y \\
\frac{d x_{2}}{d t}=a_{2} x_{2}-b_{2} x_{2} y \\
\frac{d y}{d t}=-c y-d_{1} x_{1} y+d_{2} x_{2} y\end{array}\end{array}$ & $\begin{array}{c}a_{1}, a_{2}-\text { the birth rate of the victims; } \\
b_{1}, b_{2}-\text { the meeting of victim's rates with the preda- } \\
\text { tor; } \\
c-\text { the predator mortality rate; } \\
d_{1}, d_{2}-\text { the fertility of predators. }\end{array}$ \\
\hline
\end{tabular}

Note that without limitation of judgment, in the work are implemented of numerical methods of solving systems of differential equations are implemented: the Euler method; the fourth-order Runge-Kutta method; modified Euler method and Adams-Bashfort method. They are well known, do not require further explanation and are described in detail in the literature, for example [4].

Results of numerical experiments. As noted earlier, the software supports a plug-in system, benchmarking numerical integration methods, and generating work reports [9].

Let us dwell on a detailed overview of the program. During the program download, the program logo is displayed - the program starts and the welcome window (fig. 1).

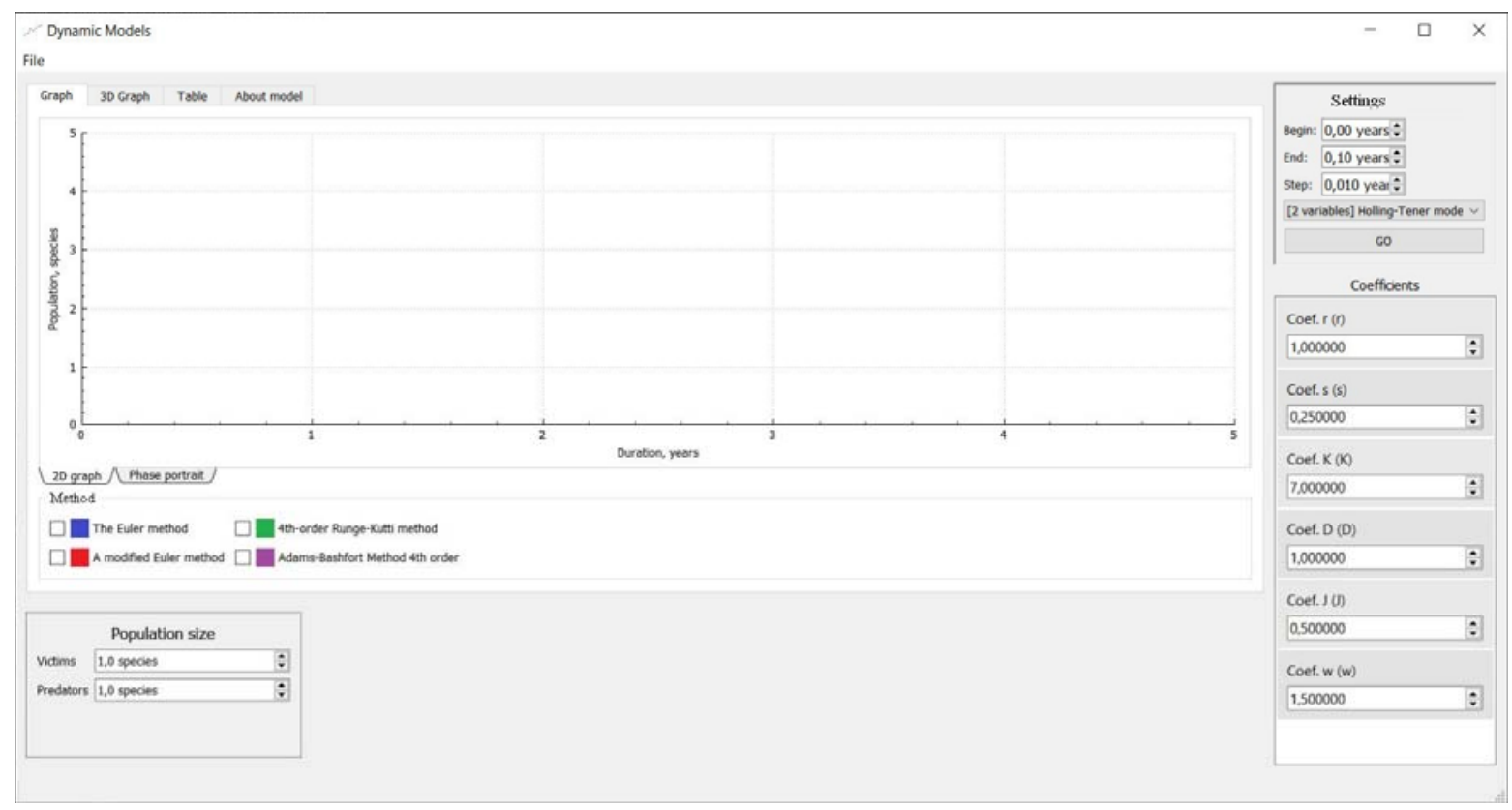

Fig. 1. The main program window

The main window is divided into several separate segments, corresponding to certain actions. One of the main panels in the program is the panel for selecting the model and adjusting its parameters (Fig. 1 top right). In order to improve and speed up the work of the software, all models are loaded before the main window appears. As defined earlier, the model is a plug-in, which is a special file that complements the program's capabilities. The plugins have a .dll extension (for Windows systems, un- 
der Linux kernel operating systems, the .so extension for macOS - .dylib). The customization panel also allows the user to configure numerical integration options, such as changing the start and end times of simulation simulations.

The next panel that is present in the program is the coefficient panel (fig. 1, bottom right). By default, classic variants of their values are offered after the model is selected.

The central place is to the work area (figs. 1,2), which displays the results of work with the selected model. The panel stores the elements (visualization panels) in separate tabs. The graph shows the process of changing species populations over time. The abscissa shows the duration in units of simulation (for example, years), and the ordinate axis is represents the number of each species at a given moment.

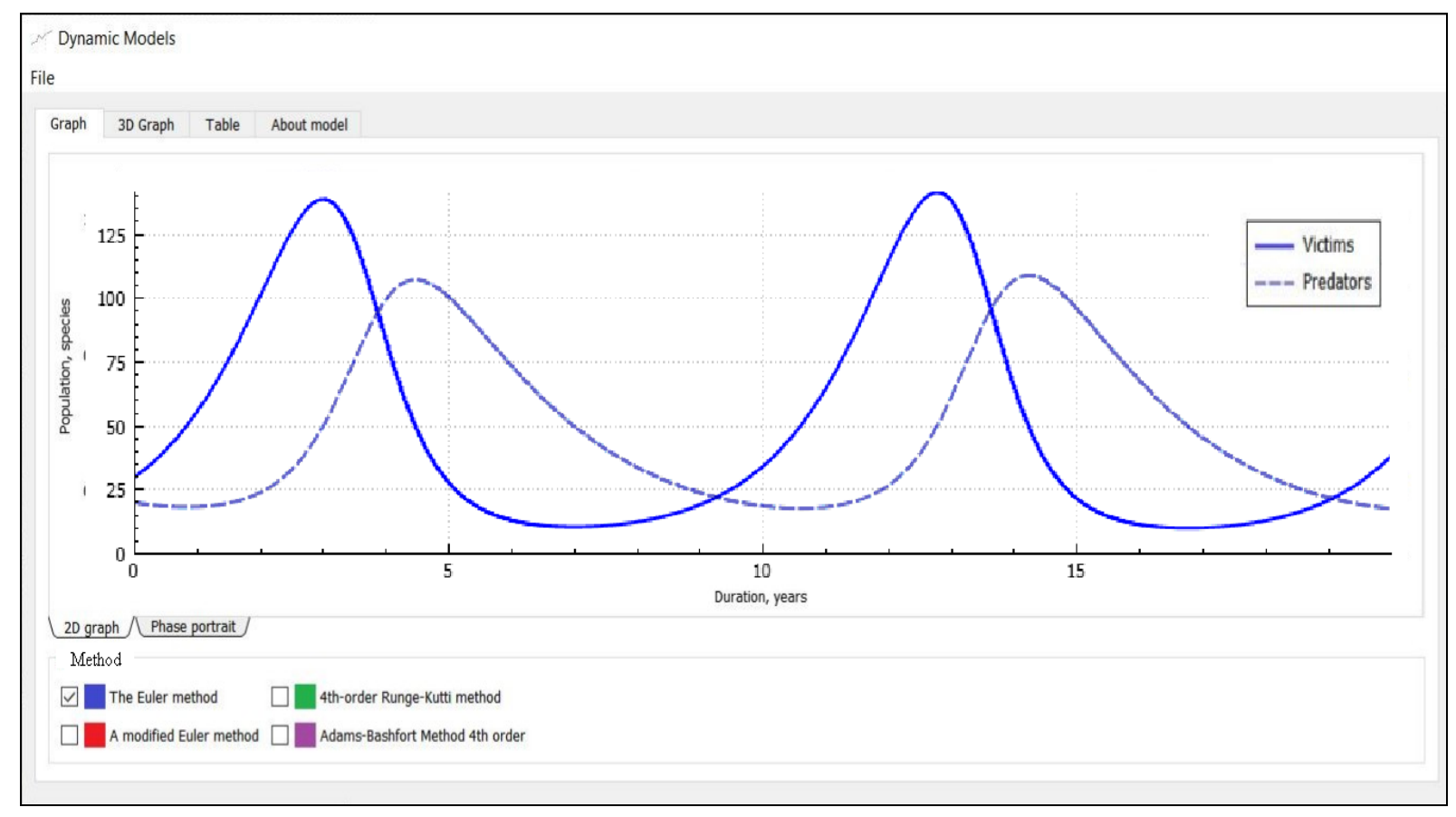

Fig. 2. 2D graph of results

The software interface contains is a selection of numerical methods of the integration. As you know, each method has its own order of accuracy, so it is possible to perform a comparative analysis: switching them on or off at the same time. For clarity, methods are depicted in their colors. When working with graphs it is possible to move with the mouse in the graph, in addition, if necessary, you can reduce or enlarge parts of it. Without limitation, consider the model of the Lotka-Volterra (fig. 2). The solution is obtained using Runge-Kutta method the first-order (that is, the Euler method).

It is possible to construct a phase portrait of the system (fig. 3) on the example of the same Lotka-Volterra model. For models with three roles it is possible to construct 3D graphs (fig. 4).

The software allows you to perform qualitative research and analysis of models.

In particular, the use of software tools for the Lotka-Volterra model allows two stationary points to be obtained:

1) the number of predator and victims in populations is zero $(x=0, y=0)$;

2) the number of predator and victims is $x=\gamma / \beta, y=\alpha / \beta$.

An analysis of the stability of stationary points shows that the first one (zero) is a saddle and the second one is a focus [5]. The Indicator Lyapunov exponent for focus is purely imaginary, so it is impossible to conclude from a linear analysis that the stability or instability of focus is impossible. However, for the Lotka-Volterra equations, there is an integral of motion that shows that the phase trajectories are closed curves, within which there is a focus [8]. 
The main feature of the Holling-Tanner model is that the oscillations are ultimately determined by the limit cycle of the phase portrait, which can be stable at $s<r(K-D+2) / K(D+1)$. It determines the amplitude of oscillations, which are set in a stationary mode of the system. In this case, the oscillations can either dampen over time and increase, while approaching stationary oscillations [8].

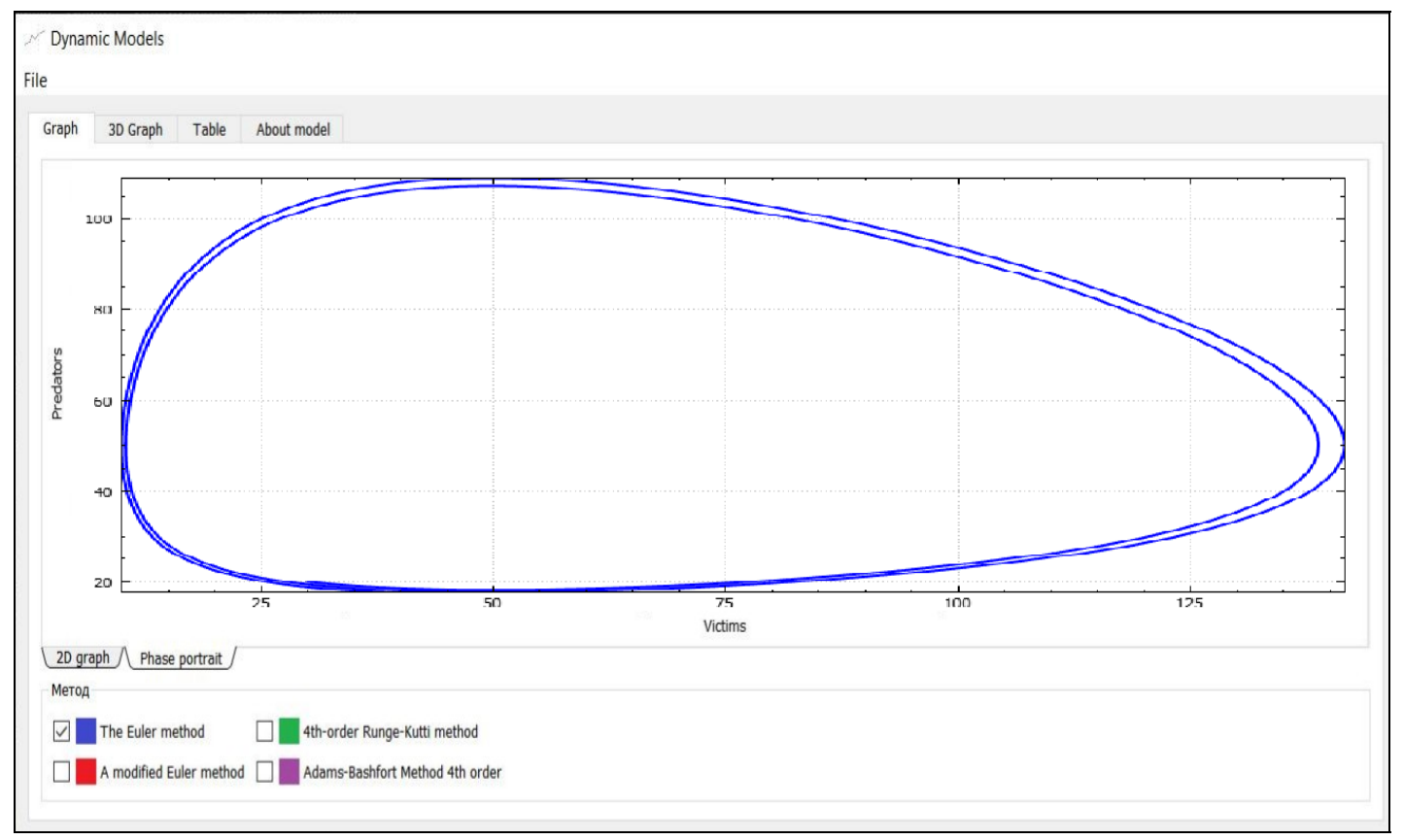

Fig. 3. The portrait of the system phase

For the Lotka-Volterra model with a logistic correction, the information system will give three points of equilibrium. An additional parameter in this model allows to control the damping of oscillations (oscillations) of the model.

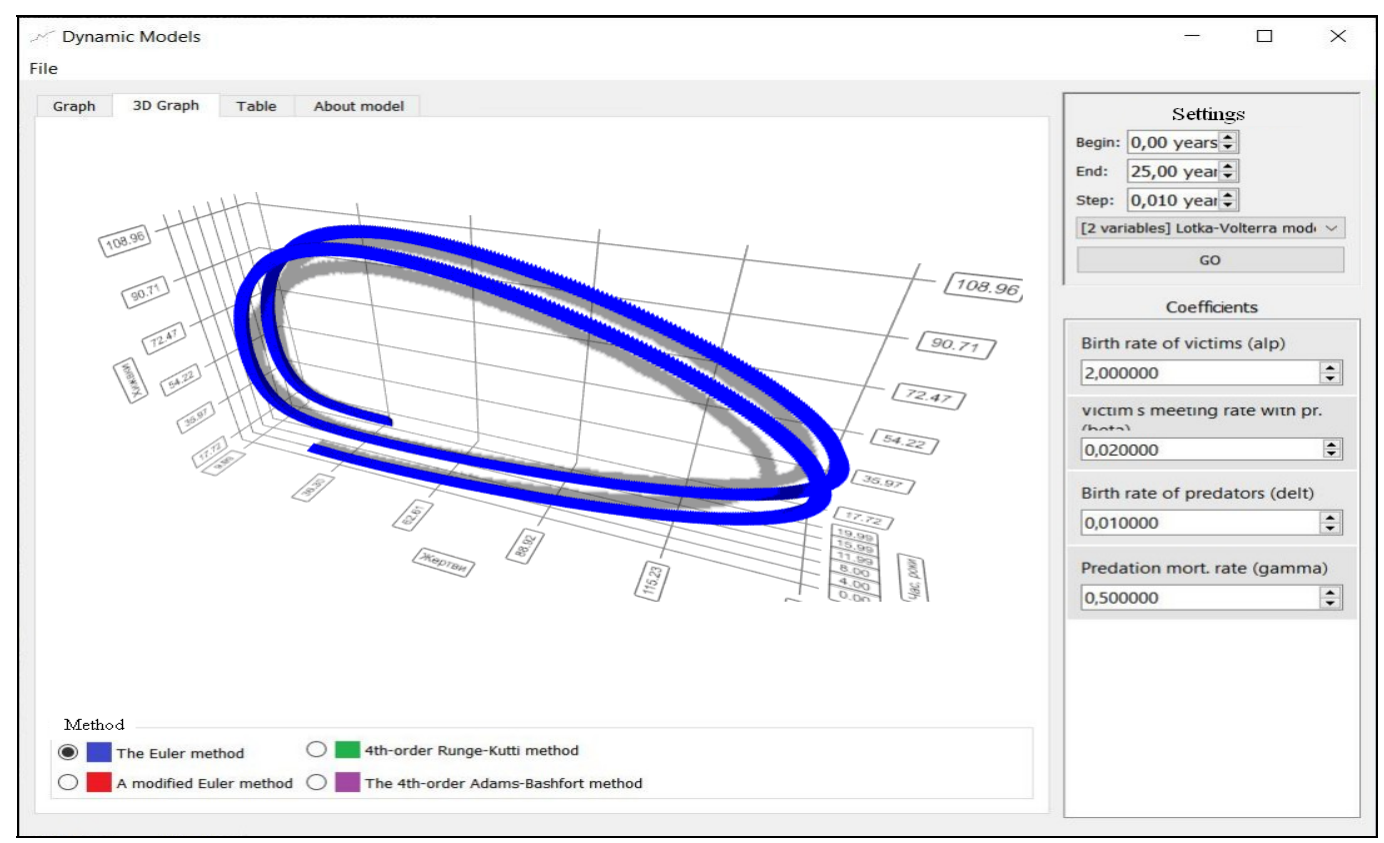

Fig. 4. 3D graph of simulation result 


\begin{tabular}{l} 
Export \\
The Euler Method \\
Data \\
$\square$ Initial data \\
$\square$ Table \\
$\square$ The final data \\
Graphic data \\
$\square$ Save the graph \\
$\square$ Save the phase portrait \\
OK \\
\hline
\end{tabular}

Fig. 5. The window of the save of the report
As it is easy to see, with these model parameters, the oscillatory process in it obviously dampens and a long equilibrium is established between the number of populations of predators and victims. The phase portrait acquires a steady focus, the shape of the phase portrait indicates a rather small linearity of this system. Therefore, the oscillations resemble a damped sine wave. Where $\alpha<0$ an unstable focus is formed and the oscillations begin to increase.

The steps of storing data step by step for further use and analysis are presented in fig. 5, 6 .

The general description of each model, the description of its parameters, the phase portrait and its qualitative analysis are in a separate tab "About model".

The created software product enables: to carry out simulation modeling with models, choosing different methods of numerical integration; adjust model parameters and get experiment results; provides qualitative research of models and their analysis.

It should be noted that an operating system installer has been created to work with the software.

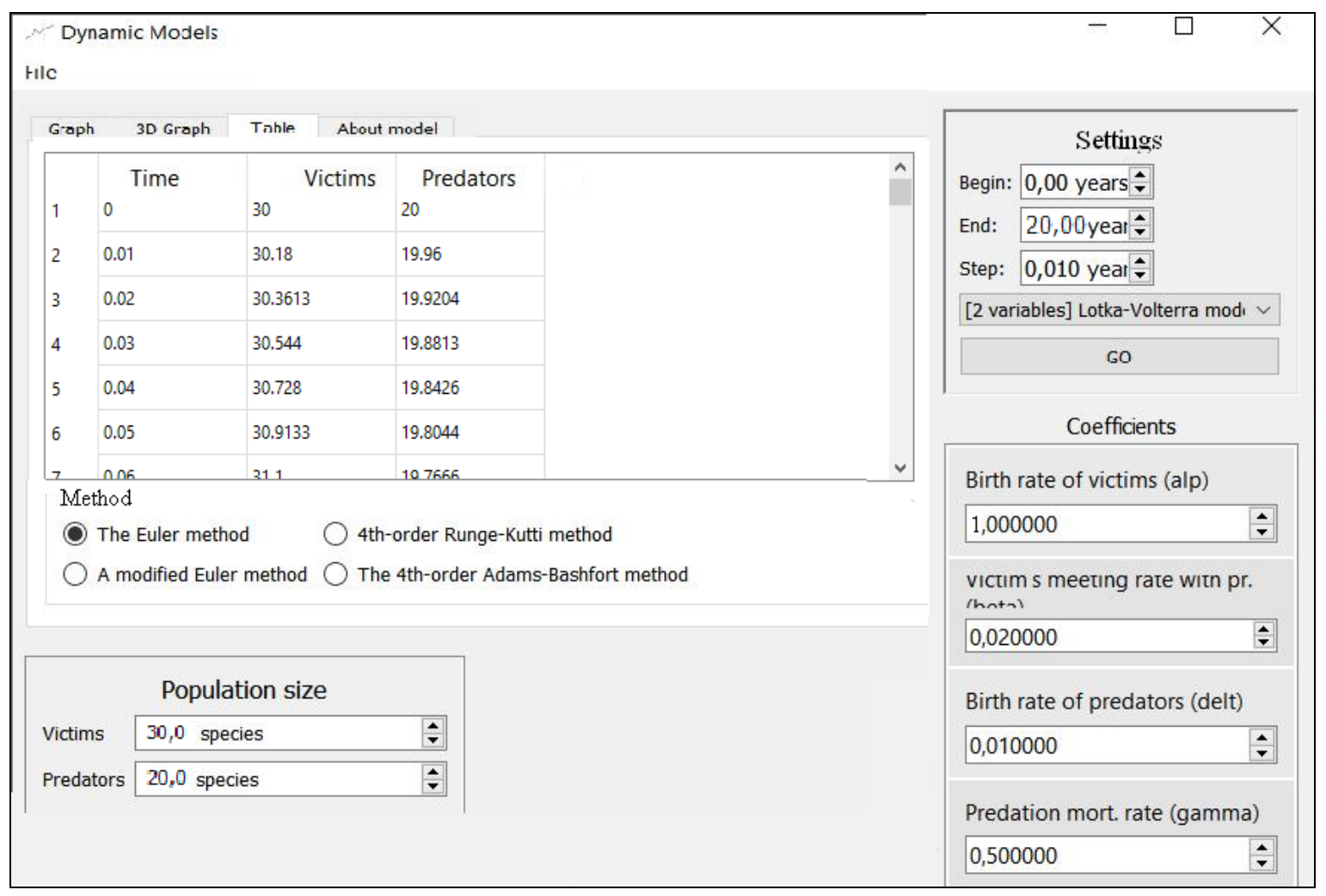

Fig. 6. The table of results

The user can choose not only the way to install the software product, create and display a shortcut on the desktop, the language of communication (Ukrainian, English, Russian), but also the operating system bit.

\section{Conclusions and prospects for further research}

Scientific direction nonlinear dynamics of complex systems, including species competition, is of practical and applied importance in both humanities and natural sciences. Qualitative research and 
analysis of such systems is impossible without the use of information technology. An information support system for simulation modeling is created in the work; structural and functional features of the information system are described; conceptual design and design of its logical model; system software (C ++ programming language, $\mathrm{Qt}$ framework) described; its mathematical support (nonlinear dynamic models and numerical methods) is presented. The created software of simulation modeling of systems of competition of species, in particular, can be useful in the study of complex dynamic processes in different subject areas: economic, social, environmental and others, or in the educational process, which is confirmed by work [10].

\section{References}

[1] Holling-Tanner Predator-Prey Model with State-Dependent Feedback Control [Electronic resource] // Discrete Dynamics in Nature and Society; Jin Yang, Guangyao Tang, Sanyi Tang, 2018. URL: https://doi.org/10.1155/2018/3467405 (date of appeal 26.05.2019). Screen name.

[2] Complex Dynamical Behavior of a Predator-Prey System with Group Defense [Electronic resource] // Mathematical Problems in Engineering; Jianglin Zhao, Min Zhao, Hengguo Yu, 2013. URL: http://dx.doi.org/10.1155/2013/910349 (date of appeal 26.05.2019). Screen name.

[3] Zelentsov D.G., Korotkaya L.I. Tehnologii vyichislitelnogo intellekta v zadachah modelirovaniya dinamicheskih sistem: monografiya [Technologies of computational intelligence in tasks of dynamic systems modeling: monograph]. Dnepr: Balans-Klub, 2018. 178 s. (DOI: http://dx.doi.org/10.32434/mono-1-ZDG-KLI). [in Russian].

[4] Samarskiy A.A., Gulin A.V. Chislennyie metodyi: Ucheb, posobie dlya vuzov [Numerical methods: allowance for universities]. M.: Nauka. Gl. red. fiz-mat. lit, 1989. 432 s. [in Russian].

[5] Terehov S.V. Fraktalyi i fizika podobiya [Fractals and similarity physics]. Donetsk: "Tsifrovaya tipografiya", 2011.255 s. [in Russian].

[6] Bazyikin A.D. Nelineynaya dinamika vzaimodeystvuyuschih populyatsiy: uchebnik [Nonlinear dynamics of interaction of populations: textbook]. Moskva-Izhevsk: Institut kompyuternyih issledovaniy, 2003. 368 s. [in Russian].

[7] Zaripov Sh.H., Nikonenkova T.V., Tolmacheva S.A. Modeli dinamiki populyatsiy na osnove differentsialnyih uravneniy: realizatsiya $\mathrm{v}$ srede $\mathrm{R}$ [Models of population dynamics based on differential equations: implementation in the environment R]. Kazan: Izd-vo Kazanskogo federalnogo universiteta, 2017. 30 s. [in Russian].

[8] Dyakonov V.P., Abramenkova, I.V., Penkov, A.A. Osnovyi matematiki i matematicheskoe modelirovanie. Chast 3 [Basics of Mathematics and Mathematical Modeling. Part 3]. Smolensk, Smolenskiy gosudarstvennyiy pedagogicheskiy universitet, 2003. 198 s. [in Russian].

[9] Rott O.S., Korotka L.I. Informacijna pidsy`stema chy`sel`nogo rozv'yazannya sy`stemy` rivnyan' Lotky'-Vol'terry' [Information subsystem of the numerical resolution of the systems Lotka-Volterra equations]. Komp'yuterne modelyuvannya ta opty`mizaciya skladny`x sy`stem (KMOSS-2017) - Computer modeling and optimization of complex systems (CMOCS-2017), 2017. S. 149-151. (DOI: 10.32434/CMOCS-2017). [in Ukrainian].

[10] Korotka L.I., Rott O.S. Svidotstvo № 82774 pro reiestratsiiu avtorskoho prava na tvir. Ukraina. Kompiuterna prohrama «Imitatsiine modeliuvannia neliniinykh dynamichnykh system konkurentsii vydiv» [Certificate № 82774 of registration of copyrights on the work. Ukraine. Computer program "Simulation of Nonlinear Dynamic Systems of Species Competition"]; stated 20.12.2018; published 25.01.2019, newsletter № 52. [in Ukrainian]. 


\section{ІНФОРМАЦЙНА ПІДТРИМКА МОДЕЛЮВАННЯ НЕЛІНІЙНИХ ДИНАМІЧНИХ СИСТЕМ КОНКУРЕНЦІЇ ВИДІВ Коротка Л.І., Ротт О.С.}

\section{Реферат}

У роботі розроблено та описано програмний інструментарій для імітаційного моделювання нелінійних динамічних систем. Розглядається клас задач, які пов'язані 3 конкуренцією видів. Такі задачі мають прикладне значення в природничих, соціальних, економічних науках тощо. Інформаційна підтримка дозволяє здійснювати якісне дослідження та аналіз систем на моделях Лотки-Вольтерри та іiі модифікацій, Жакоба-Моно, Холлінга-Теннера. Для їх реалізації використовуються одно- та багатокрокові чисельні методи.

Програмний продукт містить плагіни, кожен 3 них представляє собою динамічну модель, яка реалізує обчислювальний алгоритм та індивідуальні дані: назва моделі, подання формул моделі, їі опис, назви коефіцієнтів, назви моделей ролей, початкові значення для параметрів та ролей. Структурними елементами та функціями інформаційної системи $є$ :

- робота із зовнішніми даними: експорт результатів програми у вигляді звіту;

- робота 3 плагінами та динамічними моделями: завантаження файлів з розширенням .dll (наприклад, для Windows) зі спеціального каталогу «плагіни» в систему для подальшої обробки;

- обчислення з певними параметрами, які передаються екземпляру плагіна, повернення результатів обчислень для подальшої обробки в систему;

- візуалізація результатів: після обчислень відбувається відображення результатів (2Dдіаграма час-популяція, тривимірний графік, таблиця чисельних результатів, фазовий портрет системи);

- відображення елементів управління: панель інтегрування, панель початкових вхідних даних та коефіцієнтів відповідної моделі, віджет візуалізації (2D та 3D графіка, фазові портрети, таблиця результатів).

При розробці програмного інструментарію було виконано концептуальне проектування та проектування його логічної моделі. Описано системне програмне (мова програмування $\mathrm{C}++$ та фреймворк Qt) та математичне забезпечення.

Створений програмний продукт імітаційного моделювання конкуренції видів може бути корисним при вивченні складних динамічних систем у різних предметних областях та в навчальному процесі.

\section{Література}

1. Jin Yang, Guangyao Tang, Sanyi Tang Holling-Tanner Predator-Prey Model with State-Dependent Feedback Control. Discrete Dynamics in Nature and Society, 2018. URL: https://doi.org/10.1155/2018/3467405 (дата звернення: 26.05.2019).

2. Jianglin Zhao, Min Zhao, Hengguo Yu Complex Dynamical Behavior of a Predator-Prey System with Group Defense. Mathematical Problems in Engineering, 2013. URL: http://dx.doi.org/10.1155/2013/910349 (дата звернення: 26.05.2019).

3. Зеленцов Д.Г., Короткая Л.И. Технологии вычислительного интеллекта в задачах моделирования динамических систем: монография. Днепр: Баланс-Клуб, 2018. 178 с. (DOI: https://doi.org/10.32434/mono-1-ZDG-KLI)

4. Самарский А.А., Гулин А.В. Численные методы: учеб, пособие для вузов. М.: Наука. Гл. ред. физ-мат. лит., 1989. 432 с.

5. Терехов С.В. Фракталы и физика подобия. Донецк: «Цифровая типография», 2011. 255 с.

6. Базыкин А.Д. Нелинейная динамика взаимодействующих популяций: учебник. МоскваИжевск: Институт компьютерных исследований, 2003. 368 с.

7. Зарипов Ш.Х., Никоненкова Т.В., Толмачева С.А. Модели динамики популяций на основе дифференциальных уравнений: реализация в среде R: учебно-методическое пособие. Казань: Изд-во Казанского федерального университета, 2017. 30 с. 
8. Дьяконов В.П., Абраменкова И.В., Пеньков А.А. Основы математики и математическое моделирование. Часть $3 .:$ учебное пособие. Смоленск, Смоленский государственный педагогический университет, 2003. 198 с.

9. Ротт О.С., Коротка Л.І. Інформаційна підсистема чисельного розв'язання системи рівнянь Лотки-Вольтерри. Комп'ютерне моделювання та оптимізаиія складних систем (КМОСС2017): матеріали III Міжнародної науково-технічної конференції (м. Дніпро, 1-3 листопада 2017 року). Дніпро: ДВНЗ УДХТУ, 2017. С. 149-151. (DOI: https://doi.org/10.32434/CMOCS2017)

10. Свідоцтво № 82774 про реєстрацію авторського права на твір. Україна. Комп’ютерна програма «Імітаційне моделювання нелінійних динамічних систем конкуренції видів» / Л. І. Коротка, О. С. Ротт (Україна). - 3 с.; Опубл. 25.01.2019 р. Бюл. № 52. 